\title{
ІНТЕЛЕКТУАЛЬНІ ОБЧИСЛЕННЯ В СИСТЕМНО УЗГОДЖЕНОМУ МОДЕЛЮВАННІ IT СИСТЕМ
}

Анотація: Розглянуто задачу побудови інформаційної моделі складної організаційно-технічної системи з використанням показників існуючого документообігу.

Ключові слова: інтелектуальні обчислення, моделювання складних систем, показники діяльності.

\section{Вступ}

Зростання складності та динамічності бізнесу призводить до необхідності контролювати все більшу кількість процесів і більшу кількість параметрів кожного процесу, отже, моделювання складних організаційно-технічних систем і використовувані моделі постійно ускладнюються. Наразі поширюються спроби моделювання таких систем за допомогою створення інтелектуального IT середовища [2].

До інтелектуальних обчислень тут віднесемо засоби аналізу досягнення цілей у складних системах, засновані на онтологічному моделюванні системи показників існуючого документообігу, множини процесів предметної області (ПО) та експертно визначеної структури цілей діяльності.

\section{Постановка задачі}

Розглянемо задачу побудови інформаційної моделі складної організаційно-технічної системи. Представники бізнесу як проблеми так і цільові стани фрормулюють у вигляді показників діяльності. 3 іншого боку в системі функціонує певний документообіг, що відтворює причино-наслідкові зв'язки між атрибутами документів, як первинними так і вторинними показниками. Таким чином документообіг є носієм суттєвої частини інформації як про шляхи реалізації поставлених цілей, так і про можливі причини проблем.

Процес побудови та ідентифікації інформаційної моделі може бути розглянутий як двонаправлена процедура. Висхідна - як формування агрегованих показників діяльності по наявним даним реального документообігу. Низхідна - як побудова дерева цілей, підцілей, задач. Це дозволить визначити місця процесу діяльності, що стримують чи дають резерв покращення цільових заданих показників.

(c) O.В. Гриша, 2015 


\section{Вирішення задачі}

Подамо структуру документообігу у вигляді комп“ютерної онтології. Комп'ютерною онтологією є формальне вираження концептуальних знань про предметну області та за своєю значимістю співставна з базою знань інтелектуальної інформаційної системи [4]. У даному випадку вона містить:

- ОК - онтологію множини об’єктів (понять, концептів) предметної області (ПО), яка розглядається як ієрархічна структура показників;

- ОП - онтологія множини процесів ПО, яка розглядається як ієрархічна структура процесів, підпроцесів, дій та операцій діяльності;

- ОЗ - онтологія ієрархії цілей, підцілей,задач, які можуть бути поставлені і вирішені в ПО

Розглянемо онтологію множини об’єктів OK через концепт “показник”, оскільки аналіз діяльності виконується експертами на базі показників, що входять до документів ПО. у вигляді моделі показників ПО.

Показники бувають первинними - такими, значення яких безпосередньо вводяться з зовнішніх чи внутрішніх джерел, та похідними - такими, значення яких формуються за допомогою певних алгоритмів (формул алгебри) з інших показників.

Інформаційну модель структури показників $P$ можна подати у вигляді

$$
\begin{gathered}
P=\left\{p_{1}, p_{2}, \ldots, p_{i}, \ldots, p_{m}\right\}, i=1, m ; m=\operatorname{Card} P \\
p_{i}=<, P_{i}{ }^{*}, F_{i}, P_{i}{ }^{*}>, P^{{ }^{*}}{ }_{i} \subseteq P, P^{*}{ }_{i} \subseteq P,
\end{gathered}
$$

де $P_{i}^{\prime}$ - кінцева множина показників, що приймають безпосередню участь у формуванні показника $p_{i}$.

$P_{i}^{\prime \prime}$ - кінцева множина показників, що безпосередньо фрормуються через показник $p_{i}$.

$F_{i}$ - кінцева множина алгоритмів отримання (можливо недовизначених) значень показника $p_{i}$.

Показники можуть поєднуватися у структурні групи, що виступають як документи. $D=\left\{d_{1} d_{2}, \ldots, d_{i}, \ldots, d_{n}\right\}, i=1, n, n=\operatorname{Card} D$ - кінцева множина документів заданої предметної області (ПО). Кожен документ в свою чергу може бути розглянутий як

$$
d_{i}=<P d_{i}, P d_{i}{ }^{6}, F d_{i}, P d_{i}{ }^{*}>, P d_{i} \subseteq P, \mathrm{Pd}_{i}{ }_{i} \subseteq P, P d{ }_{i} \subseteq P,
$$

де $P d_{i}$ - кінцева множина показників у складі документа $d_{i}$;

$P d_{i}^{\prime}$ - кінцева множина показників, що приймають безпосередню участь у формуванні показників документа $d_{i}$; 
$P d_{i}^{\prime \prime}$ - кінцева множина показників, що безпосередньо формуються через показники документа $d_{i}$;

$F d_{i}$ - кінцева множина алгоритмів отримання значень показників документа $d_{i}$.

Таким чином онтологічна модель обєектів ПО будь якого бізнесу може бути подана через концепт “показник”.

$$
O K=<P, R, F>
$$

де $P$ - множина показників ПО;

$R$ - іерархічна структура показників ПО, що визначаеться через множину відношень між показниками;

$F$ - множина алгоритмів отримання значень показників (безпосередне введення виміряних значень, чи обчислення через інші показники) .

Онтологію множини процесів ПО, яка розглядаеться як ієрархічна структура процесів, підпроцесів, дій та операцій діяльності подамо у вигляді :

$$
O \Pi=<W n, R n, P n, D n>,
$$

де $W n$ - множина процесів ПО;

$R n$ - множина відношень між процесами ПО, задає структуру технологічних процесів;

$P n$ - множина показників що супроводжують та характеризують процеси ПО;

$D n$ - множина документів, що формуються у ході виконання процесу ПО.

Скінчений орієнтований навантажений граф ОЗ з детермінованими дугами відображає онтологію ієрархії цілей:

$$
O 3=<Q, R u, P u, V u>
$$

де $Q$ - множина цілей;

$R u$ - множина відношень між цілями (підцілями, задачами) на усіх рівнях цілепокладання може бути визначеною у один з наступних способів: аналітична залежність, алгоритмічна залежність, табличне подання залежності графічне подання залежності, залежність типу “тренд”, та ін. ;

$P u$ - множина показників досягнення цілей, підцілей, вирішення задач, $P u \subseteq P n$;

$V u$ - множина вимог, що визначає досягнення цілей, підцілей, вирішення задач, задана на множині показників.

Висхідний метод аналізу показників діяльності на основі документообігу. Скористаемося моделлю $O K=<P, R, F>(3)$. де інформаційну модель структури показників $P$ визначеємо за формулами (1), що витікае з (2). 
1.Через визначену в структурі документообігу (2) множину показників $P d_{i}^{\prime}$, що приймають безпосередню участь у формуванні показників документа $d_{i}$ отримуемо вхідні фрункціональні залежності на множині показників.

Множина показників $P d_{i}^{\prime \prime}$, що безпосередньо фрормуються через показники документа $d_{i}$ належить іншим похідним документам $d_{k} \subseteq D, d_{i} \notin d_{k}$. Таким чином для первинних показників $p_{i}=<\emptyset, F_{i}, P_{i}$ " $>, P{ }^{\prime}{ }_{i} \subseteq P$, де $F_{i} \in$ процедурою первинного заповнення значення показника. Для непервинних $\forall p_{i}\left(P d^{6}{ }_{i} \subseteq P^{6}{ }_{i} P d^{\prime \prime}{ }_{i} \subseteq\right.$ $\left.P{ }^{\prime \prime}{ }_{i}\right), p_{i} \in P$ і існують залежності типу $p_{i} \rightarrow P d^{\prime{ }_{i}}{ }_{i}$, та $P d^{\epsilon_{i}} \rightarrow p_{i}$.

2. За допомогою моделі $p_{i}=<, P_{i}{ }^{6}, F_{i}, P_{i}{ }^{\prime \prime}>, \mathrm{P}^{{ }}{ }_{i} \subseteq P, P{ }_{i} \subseteq P$ (1) та отриманих залежностей $p_{i} \rightarrow P d^{\prime}{ }_{i}$, та $P d^{\star}{ }_{i} \rightarrow p_{i}$ виконаемо для кожного непервинного показника $p_{i} \in P$ транзитивне замикання $T^{+}\left(p_{i}\right)$ для формування дерева його впливу, оскільки $P_{i}$ " $=T^{+}\left(p_{i}\right)$ та зворотне транзитивне замикання $T^{-}\left(p_{i}\right)$ для отримання дерева його формування, оскільки $P_{i}{ }^{6}=T-\left(p_{i}\right)$. Для цього можна скористатися алгоритмом Флойда чи Уоршелла.

Зауважимо, що у складі дерев можуть бути показники недовизначені та такі, що протилежно впливають не інтегральний показник та впливають один на інший.

3. Для обрахунку області допустимих альтернатив реалізації цілей необхідно, щоб модель показників (3) була узгодженою. Визначення відношень залежності дає змогу скористатися моделлю (3) і відновити загальну структуру $R$ на множині показників $P$ i проаналізувати її на узгодженість з використанням алгоритмів $F$.

Сформулюємо і умови узгодженості моделі (3):

1. Не повинно існувати незбалансованих відношень між множинами показників, що приймають безпосередню участь у формуванні показників документа $d_{k}$ та множиною показників, що безпосередньо фрормуються через показники документа $d_{i}$ для кожного $d_{k} \in D$ та $d_{i} \in D$. Тобто:

$$
P d_{i}^{\prime}=\bigcup_{k \in K} P d_{k}^{\prime \prime}, P d_{k}^{\prime \prime} \in P d_{i}^{\prime},
$$

де $K$ - множина документів $d_{k} \in K, K \subseteq D$, що мають показники для безпосереднього формування показників документа $d_{i}$.

2. Не повинно існувати циклів у графрі формування кожного з показників. Для кожного не первинного показника дерево формування повинно мати листовими показниками первинні показники.

4. Дана модель дає змогу поставити і вирішити наступну задачу системного аналізу - визначення множини найбільш представницьких показників для ідентифікації цільових вимог, для найбільш повного контролю за процесом діяльності. 
Сфрормулюемо критерій оптимальності для цільового показника у визначеному сенсі, як

$$
\begin{gathered}
F=\underset{i}{\arg \max }\left|P_{i}^{0}\right|, p_{l} \in P_{i}^{0}, p_{l}=<\emptyset, F_{i}, P_{l} ">, \mathrm{P}^{\prime} \subseteq \subseteq P, P_{i}^{0} \subseteq T^{-}\left(p_{i}\right) ; \\
F \rightarrow \max
\end{gathered}
$$

Низхідний метод формування структури цілей системи. Для формування структури цілей системи $O 3=<Q, R u, P u, V u>$ (5) можна скористатися наступною послідовністю етапів: структуризація цілей проекту; вибір показників моделі і аналіз доступної інформації про них, включаючи тип взаємодії; первинну оцінку показників і їх взаємозв'язків; узгодження оцінок. аналіз доступної інформації для моделі ведеться по декільком напрямкам: визначення відомостей, необхідних для оцінки окремих показників і залежностей; перевірка достовірності; виявлення суперечностей і встановлення, по можливості, їх причин; ранжування джерел даних по надійності (наприклад, бухгалтерська звітність підприемств перед податковою інспекцією звичайно буває надійнішою, ніж відомості, що надаються тими ж підприемствами в органи держстатистики).

Для обчислення області допустимих альтернатив реалізації цілей необхідно, щоб модель ціле визначення була узгодженою. Обмеження узгодженості для моделі структури досягнення цілей проекту подані у [3].

Низхідний метод формування структури процесу діяльності. Для побудови структури процесу діяльності - модель:

$$
O \Pi=<W n, R n, P n, D n>,
$$

можна скористатися стандартом IDF0 і зв'язати результати певних елементів діяльності з показниками, що наявні і в структурі показників документообігу.

Обчислення області прийняття рішень для реалізації цілей на системі показників. Задача пошуку найкращих рішень для реальних завдань бізнесу має завелику обчислювальну складність і не завжди оправдана з точки зору прийняття рішень. Тому доцільно перейти до менш ресурсномісткої задачі - задачі задоволення обмежень з навантаженням (weighted constraint satisfaction problem (WCSP)).

Моделлю такої задачі буде

$$
M^{W S C P}=<G^{p}, Z, F>,
$$

де $G^{p}$ - граф показників досягнення цілей діяльності системи;

$Z$ - множина доменів значень показників;

$F$ - множина функцій , завдана на показниках системи надає переваги на множині рішень. 
Методи дослідження комбінаторних завдань експоненціальної складності припускають пошук поліноміальних або навіть лінійних підкласів задач і способів їх ідентифікації (розпізнавання). Однак, розмірність такої задачі є похідною від складності структури цілей і складності та розмірності функцій переваг. Тому у загальному ця задача теж може виявитися np-складною і потребуватиме знаходження певних евристик для ефективного вирішення [2]. Адекватним математичним апаратом і програмним забезпеченням може бути поєднання можливостей алгоритму поглинаючого виключення (bucket eliminatin BE)[1] для знаходження потенційно хороших областей простору пошуку та використання генетичних алгоритмів для дослідження цих областей.

\section{Висновки}

Таким чином, співставлення моделей структур показників, процесів та цілей діяльності, дає можливість визначити резерви впливу на показники діяльності та отримати системно узгоджену модель складної організаційно-технічної системи.

\section{Список використаних джерел}

1. Dechter R. Backet elimination: a unifying framework for reasoning // ACM Press.- 1996. - 28, N61.- P. 1-51.

2. Gruber, T. R. 1993. A translation approach to portable ontology specifications // Knowledge Acquisition, 1993.5 (2):p p. 199-220.

3. Гриша О.В., Тютюнник С.В..Задачі структуризації цілей розвитку бізнесу на основі недовизначених моделей [Текст]: матеріали збірника наукових праць "Управління розвитком складних систем”, Київ, 2013 р.- 203 с. . - В надзаг.: МОН України, Київський національний університет будівництва і архітектури. C.82-86.

4. Массель Л.В. Применение онтологического, когнитивногои событийного моделирования для анализа развития чрезвычайных ситуаций в энергетике // Проблемы безопасности и чрезвычайных ситуаций. - 2010. - № 2. - С. 34-43.

Отримано 20.04.2015 p. 